\title{
Economic evaluation of initial antiretroviral therapy for HIV-infected patients: an update of Italian guidelines
}

This article was published in the following Dove Press journal:

ClinicoEconomics and Outcomes Research

2 October 2013

Number of times this article has been viewed

\author{
Giorgio L Colombo ${ }^{1,2}$ \\ Sergio Di Matteo ${ }^{2}$ \\ Andrea Antinori ${ }^{3}$ \\ Massimo Medaglia ${ }^{4}$ \\ Silvia Murachelli ${ }^{3}$ \\ Giuliano Rizzardini ${ }^{5}$ \\ 'Department of Drug Sciences, \\ University of Pavia, Pavia, Italy; \\ ${ }^{2}$ SAVE - Studi Analisi Valutazioni \\ Economiche, Milan, Italy; ${ }^{3}$ National \\ Institute for Infectious Diseases \\ L Spallanzani, IRCCS, Rome, Italy; \\ ${ }^{4}$ Pharmaceutical Department, L. Sacco \\ Hospital, Milan, Italy; ${ }^{5}$ First Division of \\ Infectious Disease, L. Sacco Hospital, \\ Milan, Italy
}

Introduction: Highly active antiretroviral therapy (HAART) has allowed many HIV-infected patients to enjoy longer survival and a better quality of life. We performed an economic analysis to estimate the cost-effectiveness of HAART regimens in Italy for managing HIV-naïve infected patients with a viral load below 100,000 copies $/ \mathrm{mL}$.

Patients and methods: The population considered in the model consisted of adult subjects with an HIV viral load below 100,000 copies/mL who received antiretroviral HAART treatment for the first time, according to the Italian National Guidelines with recommendation grade A1. The incremental cost-effectiveness analysis of quality-adjusted life years (QALYs) was carried out by means of a Markov model. Both the outcomes (QALYs) and the costs were discounted by $3.5 \%$. The time horizon adopted in the model was 10 years. The point of view of the analysis was that of the Italian national health service.

Results: The tenofovir (TDF)/emtricitabine (FTC)/rilpivirine (RPV) single-tablet regimen (STR) $(€ 7,417.00)$ revealed the lowest mean treatment cost. TDF/FTC + raltegravir (RAL) showed a better quality of life (0.906 QALY/year), followed by TDF/FTC/RPV (STR; 0.900 QALY/year), TDF/FTC + RPV (multipill regimen) (0.889 QALY/year), and TDF/FTC + atazanavir (ATV/r) (0.886 QALY/year). TDF/FTC/RPV (STR) appeared to be the most cost-effective therapeutic choice $(€ 13,655.00)$, followed by TDF/FTC + RPV (multipill regimen) $(€ 15,803.00)$, and TDF/ FTC + efavirenz (EFV) $(€ 16,181.00)$. The sensitivity analysis on the main variables confirmed the validity of the base case scenario.

Conclusion: STR (TDF/FTC/RPV) is the most cost-effective treatment strategy compared with the other therapeutic regimens recommended by the Italian guidelines for the treatment of naïve patients with a viral load $<100,000$ copies $/ \mathrm{mL}$. The inclusion of adverse-event management of HIV-infected patients affects the cost-effectiveness ratio of all HAART regimens.

Keywords: HIV, HAART, single-tablet regimen (STR), Markov model, cost-effectiveness

\section{Introduction}

The predicted survival rate continues to grow for patients diagnosed with HIV infection. ${ }^{1}$ Thanks to highly active antiretroviral therapy (HAART), many HIV-infected patients now enjoy longer survival and a better quality of life (QoL)., ${ }^{2,3}$ These changes show the positive effects of increasing efficacy and effectiveness, but they also raise the question of what happens to the consumption of resources. In fact, this success has changed HIV infection into a chronic disease. Establishing a strong adherence to HAART regimens therefore remains a challenge for most patients. ${ }^{4,5}$ Current therapeutic options available include approved antiretroviral drugs, divided into five classes: nucleoside/nucleotide reverse-transcriptase inhibitors, nonnucleoside reverse-transcriptase
Correspondence: Giorgio L Colombo SAVE - Studi Analisi Valutazioni Economiche, 74 Via Previati, Milan 20I49, Italy

Tel +390248519230

Fax +390273960369

Email giorgio.colombo@savestudi.it 
inhibitors, protease inhibitors, fusion or entry inhibitors, and integrase inhibitors.

Considering the complexity of the disease, a recent update of Italian guidelines has been published recommending different treatments for the initial antiretroviral therapy (ART) for patients with a viral load below or above 100,000 copies/mL, ${ }^{6}$ with either multipill regimens (MPRs) or single tablet regimens (STRs), which should be evaluated in terms of lifetime costs and cost-effectiveness, among other things. These recommendations and other publications also underline that STRs are more effective in the duration of viral suppression compared to more complex ones. ${ }^{7-9}$ Moreover, rilpivirine (RPV), a new drug for HIV, (either as single agent or coformulated in STR), was licensed in Europe in $2011^{10}$ and in Italy in early $2013,{ }^{11}$ and it is already included in the national guidelines. ${ }^{6}$ How will these elements impact resource consumption in the HIV-infection care from the point of view of the Italian regional health care system? The present study, through an update of the Markov model already used in HIV settings, ${ }^{12}$ aimed to answer this question, performing an economic analysis to assess the cost-effectiveness of initial HAART regimens in patients with a viral load $<100,000.00$ copies/mL.

\section{Patients and methods}

The aim of the study was to determine the incremental costeffectiveness ratio (ICER) per quality-adjusted life years (QALYs) gained for HAART regimens, based on the 2012 Italian guidelines, for first-line treatment of HIV-infected patients. ${ }^{6}$ The cost-effectiveness analysis was performed by applying a previously published Markov model, ${ }^{12}$ which allowed us to carry out a comparison of studied ART regimens according to the previous 2010 Italian guidelines. ${ }^{13}$ In this analysis, the direct costs and effectiveness (this time considering not just the efficacy in viral load reduction but also the occurrence of adverse events) of each drug were compared with the direct costs and effectiveness of the disease's natural history (absence of treatment). The seven ART regimens considered follow the latest Italian guidelines on HAART regimens in a viral load $<100,000$ copies/mL, which represents $68.6 \%$ of Italian HIV patients, ${ }^{14}$ with recommendation grade A1 for initial treatment of HIVinfected patients. ${ }^{6}$ The analysis was carried out from the point of view of the Italian national health service (Servizio Sanitario Nazionale [SSN]). The population considered in the analysis reflects patient characteristics according to one HIV/AIDS infection report of the regional surveillance systems currently operating in Italy (epidemic update as of December 31, 2011). This population was stratified into the following health states: $25.94 \%$ of HIV-infected patients with CD4 $\geq 500$ and viremia level (VL) $\geq 50 ; 25.94 \%$ of HIV-infected patients with $351<\mathrm{CD} 4<500$ and VL $\geq 50$; $33.00 \%$ of HIV-infected patients with $201<$ CD $4<350$ and $\mathrm{VL} \geq 50$; and $15.12 \%$ of HIV-infected patients with $\mathrm{CD} 4<200$ and $\mathrm{VL} \geq 50 .^{15}$

\section{Structure of the model}

The Markov model simulates the QoL and the costs for an HIV patient for 10 years, starting from the administration of the initial treatment through 1-year cycles based on the administered ART. ${ }^{16}$ After entering the model and receiving one of the ART regimens, the patient can "move" through eight health states, defined by the CD4 cell count combined with the VLs, one AIDS state, and one death state (Figure 1).

The model assigned patients responding to the ART a VL lower than 50 copies, and allowed responders to move

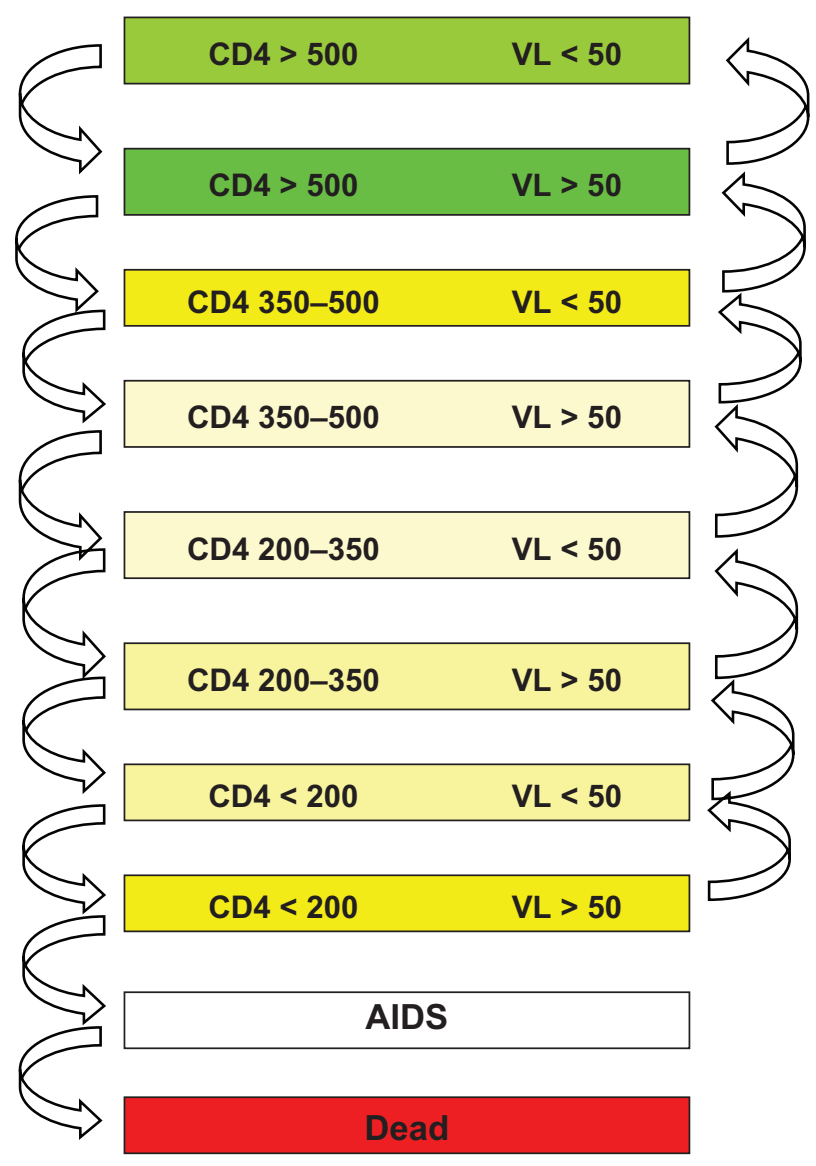

Figure I Structure of the Markov model. ${ }^{12}$

Note: Copyright $\odot$ 201I, Dove Medical Press Ltd. Reproduced with permission from Colombo GL, Colangeli V, Di Biagio A, Di Matteo S, Viscoli C, Viale P. Costeffectiveness analysis of initial HIV treatment under Italian guidelines. Clinicoecon Outcomes Res. 201 I;3:197-205. ${ }^{12}$

Abbreviation: $\mathrm{VL}$, viremia level; $\mathrm{CD} 4$, cell. 
within the CD4 classification. In the case of failure of firstline treatment, the model presumed a VL $>50$ copies for the patients and CD4 values following the trend of the untreated population. ${ }^{17}$ Finally, the model was completed with appropriate occurrence values to define probabilistic knots, and with precise cost estimates, in order to finalize the comparison, as described below. The considered outcome measures were QALYs and direct health costs calculated for the year 2012. Both the outcomes (QALYs) and the costs were discounted by $3.5 \%{ }^{18}$ The time horizon adopted in the model was 10 years. Modeling was undertaken using Excel 2010 (Microsoft, Redmond, WA, USA).

\section{Immunologic response and quality-adjusted life years}

Table 1 shows the immunologic responses for each of the therapeutic regimens studied, as indicated in the Italian guidelines, and reported in the references. ${ }^{19-30}$ In cases of unavailable data, it was assumed that the response remained constant at the last observed value by applying the last-value-carried-forward technique. ${ }^{12}$ The effectiveness indicators considered in this economic evaluation were QALYs. The utility values associated with the eight health states identified by CD4-cell count, published in a study by Simpson et al, ${ }^{16}$ were calculated by means of the EuroQol five-dimension questionnaire (www.euroqol.org).
For $\mathrm{CD}^{+}{ }^{+}$values $>500$ cells $/ \mu \mathrm{L}$, the utility score was 0.9460 ; for $\mathrm{CD}^{+} 351-500$ cells $/ \mu \mathrm{L}$, the utility score was 0.9330 ; for CD4 ${ }^{+} 201-350$ cells $/ \mu \mathrm{L}$, the utility score was 0.9310 ; for $\mathrm{CD}^{+}<200$ cells $/ \mu \mathrm{L}$, the utility score was 0.8300 . Regarding the grade 3-4 adverse events considered ${ }^{19-30}$ as a result of the specific regimen, the utility score for various states of health was reduced to $-0.052 .{ }^{16}$

\section{Resource consumption and cost analysis}

Table 2 shows the average annual costs for each first-line regimen. The purchase costs of drugs were calculated based on the reimbursement price paid by the Italian SSN, which takes into account price updates effective from the beginning of 2013 (VAT excluded). ${ }^{31}$ For every health state defined by the CD4 cell count, an additional health cost associated with patients was assumed, including a further consumption of health resources due to hospitalization, outpatient care, specialist examinations, laboratory tests, diagnostic procedures, and other drugs (Table 3 ). Costs were estimated based on the results of research by Rizzardini et al. ${ }^{32}$ The cost of the AIDS health state was put at $€ 10,224.63 .{ }^{32}$ Table 1 shows the probability of adverse events for the different regimens; in addition to a utility-score decrease, we assumed a mean additional cost per year for adverse event of $€ 2,430.12$, only including hospitalization cost and other drugs. ${ }^{32}$

Table I Immunologic response and adverse events per different treatment regimen

\begin{tabular}{|c|c|c|c|c|c|c|c|c|c|c|c|}
\hline & \multicolumn{10}{|l|}{ Year } & \multirow[t]{2}{*}{ Source } \\
\hline & I & 2 & 3 & 4 & 5 & 6 & 7 & 8 & 9 & 10 & \\
\hline \multicolumn{12}{|l|}{ Response rate } \\
\hline $\begin{array}{l}\text { TDF/FTC + RPV } \\
\text { (single-tablet regimen) }\end{array}$ & $89.00 \%$ & $89.00 \%$ & $89.00 \%$ & $89.00 \%$ & $89.00 \%$ & $89.00 \%$ & $89.00 \%$ & $89.00 \%$ & $89.00 \%$ & $89.00 \%$ & 19 \\
\hline TDF/FTC + RPV & $90.00 \%$ & $84.00 \%$ & $84.00 \%$ & $84.00 \%$ & $84.00 \%$ & $84.00 \%$ & $84.00 \%$ & $84.00 \%$ & $84.00 \%$ & $84.00 \%$ & 20 \\
\hline TDF/FTC + EFV & $75.00 \%$ & $90.00 \%$ & $90.00 \%$ & $90.00 \%$ & $90.00 \%$ & $90.00 \%$ & $90.00 \%$ & $90.00 \%$ & $90.00 \%$ & $90.00 \%$ & 21 \\
\hline $\mathrm{TDF} / \mathrm{FTC}+\mathrm{ATV} / \mathrm{r}$ & $82.00 \%$ & $89.00 \%$ & $89.00 \%$ & $89.00 \%$ & $89.00 \%$ & $89.00 \%$ & $89.00 \%$ & $89.00 \%$ & $89.00 \%$ & $89.00 \%$ & 21 \\
\hline $\mathrm{TDF} / \mathrm{FTC}+\mathrm{DRV} / \mathrm{r}$ & $81.00 \%$ & $81.00 \%$ & $81.00 \%$ & $67.50 \%$ & $67.50 \%$ & $67.50 \%$ & $67.50 \%$ & $67.50 \%$ & $67.50 \%$ & $67.50 \%$ & 22,23 \\
\hline TDF/FTC + RAL & $92.50 \%$ & $92.50 \%$ & $94.00 \%$ & $93.00 \%$ & $93.00 \%$ & $93.00 \%$ & $93.00 \%$ & $93.00 \%$ & $93.00 \%$ & $93.00 \%$ & $24-27$ \\
\hline $\mathrm{ABC} / 3 \mathrm{TC}+\mathrm{EFV}$ & $64.00 \%$ & $85.00 \%$ & $85.00 \%$ & $85.00 \%$ & $85.00 \%$ & $85.00 \%$ & $85.00 \%$ & $85.00 \%$ & $85.00 \%$ & $85.00 \%$ & 21 \\
\hline $\mathrm{ABC} / 3 \mathrm{TC}+\mathrm{ATV} / \mathrm{r}$ & $83.00 \%$ & $83.00 \%$ & $83.00 \%$ & $83.00 \%$ & $83.00 \%$ & $83.00 \%$ & $83.00 \%$ & $83.00 \%$ & $83.00 \%$ & $83.00 \%$ & 21 \\
\hline \multicolumn{12}{|l|}{ Adverse events } \\
\hline $\begin{array}{l}\text { TDF/FTC + RPV } \\
\text { (single-tablet regimen) }\end{array}$ & $7.00 \%$ & $7.00 \%$ & $7.00 \%$ & $7.00 \%$ & $7.00 \%$ & $7.00 \%$ & $7.00 \%$ & $7.00 \%$ & $7.00 \%$ & $7.00 \%$ & 19 \\
\hline TDF/FTC + RPV & $16.00 \%$ & $16.00 \%$ & $16.00 \%$ & $16.00 \%$ & $16.00 \%$ & $16.00 \%$ & $16.00 \%$ & $16.00 \%$ & $16.00 \%$ & $16.00 \%$ & $20,28,29$ \\
\hline TDF/FTC + EFV & $19.65 \%$ & $19.65 \%$ & $19.65 \%$ & $19.65 \%$ & $19.65 \%$ & $19.65 \%$ & $19.65 \%$ & $19.65 \%$ & $19.65 \%$ & $19.65 \%$ & 21 \\
\hline TDF/FTC + ATV/r & $19.65 \%$ & $19.65 \%$ & $19.65 \%$ & $19.65 \%$ & $19.65 \%$ & $19.65 \%$ & $19.65 \%$ & $19.65 \%$ & $19.65 \%$ & $19.65 \%$ & 21 \\
\hline $\mathrm{TDF} / \mathrm{FTC}+\mathrm{DRV} / \mathrm{r}$ & $23.00 \%$ & $23.00 \%$ & $23.00 \%$ & $23.00 \%$ & $23.00 \%$ & $23.00 \%$ & $23.00 \%$ & $23.00 \%$ & $23.00 \%$ & $23.00 \%$ & 22,30 \\
\hline TDF/FTC + RAL & $10.00 \%$ & $10.00 \%$ & $17.00 \%$ & $17.80 \%$ & $17.80 \%$ & $17.80 \%$ & $17.80 \%$ & $17.80 \%$ & $17.80 \%$ & $17.80 \%$ & $24-27$ \\
\hline $\mathrm{ABC} / 3 \mathrm{TC}+\mathrm{EFV}$ & $33.50 \%$ & $33.50 \%$ & $33.50 \%$ & $33.50 \%$ & $33.50 \%$ & $33.50 \%$ & $33.50 \%$ & $33.50 \%$ & $33.50 \%$ & $33.50 \%$ & 21 \\
\hline $\mathrm{ABC} / 3 \mathrm{TC}+\mathrm{ATV} / \mathrm{r}$ & $33.50 \%$ & $33.50 \%$ & $33.50 \%$ & $33.50 \%$ & $33.50 \%$ & $33.50 \%$ & $33.50 \%$ & $33.50 \%$ & $33.50 \%$ & $33.50 \%$ & 21 \\
\hline
\end{tabular}

Abbreviations: TDF, tenofovir; FTC, emtricitabine; RPV, rilpivirine; EFV, efavirenz; ATV, atazanavir; DRV, darunavir; RAL, raltegravir; ABC, abacavir; 3TC, lamivudine; r, ritonavir. 
Table 2 Average annual costs for each therapeutic regimen

\begin{tabular}{ll}
\hline Treatment & $\begin{array}{l}\text { Annual cost of } \\
\text { HAART regimen }\end{array}$ \\
\hline TDF/FTC + RPV (single-tablet regimen) & $€ 7,199$ \\
TDF/FTC + RPV & $€ 7,406$ \\
TDF/FTC + EFV & $€ 7,226$ \\
TDF/FTC + ATV/r & $€ 8,813$ \\
TDF/FTC + DRV/r & $€ 8,987$ \\
TDF/FTC + RAL & $€ 10,620$ \\
ABC/3TC + EFV & $€ 6,776$ \\
ABC/3TC + ATV/r & $€ 8,363$ \\
\hline
\end{tabular}

Abbreviations: HAART, highly active antiretroviral therapy; TDF, tenofovir; FTC, emtricitabine; RPV, rilpivirine; EFV, efavirenz; ATV, atazanavir; DRV, darunavir; RAL, raltegravir; $A B C$, abacavir; $3 T C$, lamivudine; $r$, ritonavir.

\section{Sensitivity analysis}

The sensitivity analysis verified the impact of a series of variations of the base case with a large influence on the obtained results. ${ }^{14}$ A series of univariate analyses were carried out on some parameters of the simulation model, such as virological response, HAART-cost regimen, and probability of adverse events. Each parameter was varied with $\pm 10 \%$ with respect to the base-case scenario on the basis of Italian guidelines on economic evaluation. ${ }^{18}$

\section{Results}

Table 4 shows the average annual cost and the QALYs for HIV-infected patients with a viral load $<100,000$ copies $/ \mathrm{mL}$, treated with each of the first-line ART regimens in the Italian guidelines, with an A1 level of recommendation. Tenofovir (TDF)/emtricitabine (FTC)/RPV (STR, €7,417.00) shows the lowest mean treatment cost. The simulation model shows that patients treated with TDF/FTC + raltegravir have a better QoL (0.906 QALY/year), with a higher number of QALYs than with other therapeutic regimens; followed by TDF/FTC/RPV (STR, 0.900 QALY/ year), TDF/FTC + RPV (MPR, 0.889 QALY/year), and TDF/FTC + atazanavir (0.886 QALY/year). Comparing the aforementioned costs and QALYs in incremental terms
(ICER) with the no-treatment strategy, the STR of TDF/ FTC/RPV appears to be the most cost-effective therapeutic choice $(€ 13,655.00)$, followed by TDF/FTC + RPV (MPR, $€ 15,803.00)$ and TDF/FTC + efavirenz (EFV) (€16,181.00); the remaining strategies have an ICER value varying from $€ 17,000.00$ to $€ 25,000.00$ per QALY.

The sensitivity analysis carried out on the main variables does not highlight significant variations with respect to the base case (Table 5 and Figure 2). For instance, including an increase (10\%) in cost for one adverse event, there is a reduction of the ICER for all therapeutic regimens. On the other hand, it is worth noting that the cost per QALY increases with the increase in HAART cost; $+10 \%$ in the HAART cost means ICER increases of $+15 \%$ and $+20 \%$ for all different regimens (Table 5 and Figure 2).

\section{Discussion}

Since 1996, thanks to the discovery of new classes of drugs and molecules and especially with the introduction of combined therapies, the life expectancy and QoL of HIV patients have enormously improved. Considering the complexity of the disease, a recent update of Italian guidelines has been published recommending different treatments for initial ART for patients with viral load below or above 100,000 copies $/ \mathrm{mL}^{6}$ with either MPRs or STRs, which should be evaluated in terms of lifetime costs and cost-effectiveness, among other things. Adding new antiretroviral STRs to conventional therapies can help physicians in the choice of the best possible treatment to administer HIV patients with a viral load $<100,000$ copies/mL. Since STR is not the only available therapeutic option, it was deemed necessary to carry out a comparison with other ART regimens; the analysis therefore considered the regimens recommended, to a varying extent, by the Italian guidelines with an A1 recommendation level. The comparison was not limited to clinical efficacy, but it also evaluated adverse events and treatment costs. In particular, an incremental cost-effectiveness analysis was performed

Table 3 Average annual cost per patient and health state expressed in CD4 (excluding HAART cost) ${ }^{7,32}$

\begin{tabular}{|c|c|c|c|c|c|c|c|c|}
\hline \multirow{2}{*}{$\frac{\text { CD4 }}{\text { Viremia }}$} & \multicolumn{2}{|c|}{$>500$ cells $/ \mu \mathrm{L}$} & \multicolumn{2}{|c|}{$35 \mathrm{I}-500$ cells $/ \mu \mathrm{L}$} & \multicolumn{2}{|c|}{$20 \mathrm{I}-350$ cells $/ \mu \mathrm{L}$} & \multicolumn{2}{|c|}{$<200$ cells $/ \mu \mathrm{L}$} \\
\hline & $<\mathbf{5 0}$ & $\geq \mathbf{5 0}$ & $<\mathbf{5 0}$ & $\geq \mathbf{5 0}$ & $<\mathbf{5 0}$ & $\geq \mathbf{5 0}$ & $<\mathbf{5 0}$ & $\geq \mathbf{5 0}$ \\
\hline \multicolumn{9}{|l|}{ Other costs } \\
\hline Healthcare services & $€ \mathrm{I}, 349$ & $€ \mathrm{I}, 490$ & $€ I, 459$ & $€ I, 619$ & $€ 1,610$ & $€ \mathrm{I}, 794$ & $€ I, 700$ & $€ \mathrm{I}, 675$ \\
\hline Other drugs & $€ 325$ & $€ 254$ & $€ 366$ & $€ 377$ & $€ 510$ & $€ 266$ & $€ 840$ & $€ 648$ \\
\hline Hospitalizations & $€ 610$ & $€ 975$ & $€ 1,509$ & $€ \mathrm{I}, 488$ & $€ 719$ & $€ 2,733$ & $€ 2,798$ & $€ 5,025$ \\
\hline Total & $€ 2,284$ & $€ 2,719$ & $€ 3,333$ & $€ 3,484$ & $€ 2,839$ & $€ 4,793$ & $€ 5,337$ & $€ 7,348$ \\
\hline
\end{tabular}

Note: Copyright $\odot$ 2012, Dove Medical Press Ltd. Reproduced with permission from Rizzardini G, Bonfanti P, Carenzi L, et al. Cost-effectiveness analysis of HIV treatment in the clinical practice of a public hospital in northern Italy. Ther Clin Risk Manag. 2012;8:377-384. ${ }^{7}$ and Rizzardini G, Restelli U, Bonfanti P, et al. Cost of human immunodeficiency virus infection in Italy, 2007-2009: effective and expensive, are the new drugs worthwhile? Clinicoecon Outcomes Res. 2012;4:245-252. ${ }^{32}$

Abbreviation: HAART, highly active antiretroviral therapy. 
Table 4 Costs, QALYs, and incremental cost-effectiveness ratio (ICER) of the base-case scenario (I0-year horizon)

\begin{tabular}{|c|c|c|c|c|c|c|}
\hline Treatment & $\begin{array}{l}\text { C } \\
\text { Mean cost } \\
\text { per patient }\end{array}$ & $\begin{array}{l}\text { E } \\
\text { Mean QALYs } \\
\text { per patient }\end{array}$ & $\begin{array}{l}\text { C/E } \\
\text { Mean cost } \\
\text { per QALY }\end{array}$ & $\begin{array}{l}\frac{\Delta \mathrm{C}}{\text { Delta }} \\
\text { cost }\end{array}$ & $\begin{array}{l}\frac{\Delta E}{\text { Delta }} \\
\text { QALYs }\end{array}$ & $\begin{array}{l}\frac{\Delta C / \Delta E}{\text { ICER }} \\
\text { QALYS }\end{array}$ \\
\hline Untreated & $€ 3,461$ & 0.611 & $€ 5,667$ & & & \\
\hline $\begin{array}{l}\text { TDF/FTC + RPV } \\
\text { (single-tablet regimen) }\end{array}$ & $€ 7,417$ & 0.900 & $€ 8,238$ & $€ 3,957$ & 0.290 & $€ 13,655$ \\
\hline TDF/FTC + RPV & $€ 7,861$ & 0.889 & $€ 8,842$ & $€ 4,40$ I & 0.278 & $€ \mid 5,803$ \\
\hline TDF/FTC + EFV & $€ 7,803$ & 0.879 & $€ 8,877$ & $€ 4,343$ & 0.268 & $€|6,18|$ \\
\hline $\mathrm{ABC} / 3 \mathrm{TC}+\mathrm{EFV}$ & $€ 7,777$ & 0.865 & $€ 8,987$ & $€ 4,317$ & 0.255 & $€ \mid 6,945$ \\
\hline $\mathrm{TDF} / \mathrm{FTC}+\mathrm{ATV} / \mathrm{r}$ & $€ 9,536$ & 0.886 & $€ 10,760$ & $€ 6,076$ & 0.276 & $€ 22,045$ \\
\hline $\mathrm{ABC} / 3 \mathrm{TC}+\mathrm{ATV} / \mathrm{r}$ & $€ 9,460$ & 0.876 & $€ 10,802$ & $€ 6,000$ & 0.265 & $€ 22,631$ \\
\hline $\mathrm{TDF} / \mathrm{FTC}+\mathrm{DRV} / \mathrm{r}$ & $€ 9,462$ & 0.871 & $€ 10,866$ & $€ 6,001$ & 0.260 & $€ 23,069$ \\
\hline TDF/FTC + RAL & $€ I I, 028$ & 0.906 & $€ \mid 2,175$ & $€ 7,568$ & 0.295 & $€ 25,637$ \\
\hline
\end{tabular}

Abbreviations: QALYs, quality-adjusted life years; TDF, tenofovir; FTC, emtricitabine; RPV, rilpivirine; EFV, efavirenz; ATV, atazanavir; DRV, darunavir; RAL, raltegravir; $\mathrm{ABC}$, abacavir; 3TC, lamivudine; $r$, ritonavir.

for each regimen, in comparison to the no-treatment option, from the point of view of the Italian SSN. Such comparisons were carried out with the help of a Markov decision model over a 10-year time horizon. The model estimated QALYs as outcomes and direct health costs (drugs, medical examinations, hospitalizations, tests, and so on) as costs; these costs were attributed a value based on prices and rates as of 2012 .

The simulation-model results show that in terms of cost per gained QALY, the STR of TDF/FTC/RPV appears to the most cost-effective therapeutic choice with an ICER of $€ 13,655.00$, compared with the other therapeutic regimens recommended by the guidelines. All the ICER values of the various regimens considered by the Italian guidelines were lower than the threshold value of $€ 50,000.00$ commonly accepted at the international level. ${ }^{33}$ Though no officially established threshold is available for Italy, it is worth noting that recent guidelines by the Italian Health
Economics Association ${ }^{18}$ recommend that a threshold of $€ 25,000.00-€ 40,000.00$ be adopted. Other acceptable references of cost-effectiveness for the Italian context are $€ 36,500.00$ and $€ 60,000.00$, and have been calculated by two different authors. ${ }^{34,35}$ The sensitivity analysis on the main variables confirmed the validity of the base case. Furthermore, our results are in line with other recent pharmacoeconomic analyses, in particular the studies by Colombo et $\mathrm{al}^{12}$ and Rizzardini et $\mathrm{al},{ }^{7}$ and with the more recent costutility analyses by Moeremans et al, ${ }^{36}$ Castagna et al, ${ }^{8}$ and Maggiolo et al. ${ }^{9,37}$

We can note also that the inclusion of adverse events in the model, compared to a previously published paper in $2011,{ }^{12}$ greatly affected the cost-effectiveness ratio of all treatment regimens, highlighting a greater importance of evaluating these aspects during pharmacoeconomic analysis for all regimens for HIV patients. The same utility score used for other therapeutic regimens was applied to the STR of TDF/

Table 5 Results of one-way sensitivity analyses

\begin{tabular}{|c|c|c|c|c|c|c|c|c|c|}
\hline \multirow[t]{2}{*}{ Treatment } & \multicolumn{9}{|c|}{ Incremental cost-effectiveness ratio } \\
\hline & $\begin{array}{l}\text { Base } \\
\text { case }\end{array}$ & $\begin{array}{l}\text { HAART } \\
\text { cost } \\
-10 \%\end{array}$ & $\begin{array}{l}\text { HAART } \\
\text { cost } \\
+10 \%\end{array}$ & $\begin{array}{l}\text { Other } \\
\text { costs } \\
-10 \%\end{array}$ & $\begin{array}{l}\text { Other } \\
\text { costs } \\
+10 \%\end{array}$ & $\begin{array}{l}\text { Response } \\
\text { rate } \\
-10 \%\end{array}$ & $\begin{array}{l}\text { Response } \\
\text { rate } \\
+10 \% \\
\end{array}$ & $\begin{array}{l}\text { Adverse } \\
\text { events } \\
-10 \%\end{array}$ & $\begin{array}{l}\text { Adverse } \\
\text { events } \\
+10 \% \\
\end{array}$ \\
\hline $\begin{array}{l}\text { TDF/FTC + RPV } \\
\text { (single-tablet regimen) }\end{array}$ & $€ \mid 3,655$ & $€ \mathrm{II}, 202$ & $€ 16,107$ & $€ 13,675$ & $€ 13,635$ & $€|4,7| 3$ & $€|2,82|$ & $€ 13,720$ & $€ 13,590$ \\
\hline TDF/FTC + RPV & $€ 15,803$ & $€ 13,185$ & $€|8,42|$ & $€|5,74|$ & $€ \mid 5,865$ & $€ 17,070$ & $€ \mid 4,802$ & $€ 15,746$ & $€ 15,859$ \\
\hline TDF/FTC + EFV & $€|6| 8 \mid$, & $€ \mid 3,548$ & $€|8,8| 4$ & $€ 16,079$ & $€ \mid 6,283$ & $€ \mid 7,407$ & $€ 15,219$ & $€ 16,100$ & $€ 16,262$ \\
\hline $\mathrm{ABC} / 3 \mathrm{TC}+\mathrm{EFV}$ & $€ 16,945$ & $€ \mid 4,375$ & $€ 19,516$ & $€|6,69|$ & $€ 17,200$ & $€ 18,305$ & $€ \mid 5,878$ & $€ 16,736$ & $€ 17,154$ \\
\hline $\mathrm{TDF} / \mathrm{FTC}+\mathrm{ATV} / \mathrm{r}$ & $€ 22,045$ & $€ 18,835$ & $€ 25,255$ & $€ 21,947$ & $€ 22,143$ & $€ 23,595$ & $€ 20,817$ & $€ 21,973$ & $€ 22,116$ \\
\hline $\mathrm{ABC} / 3 \mathrm{TC}+\mathrm{ATV} / \mathrm{r}$ & $€ 22,631$ & $€ 19,472$ & $€ 25,790$ & $€ 22,393$ & $€ 22,869$ & $€ 24,388$ & $€ 21,239$ & $€ 22,366$ & $€ 22,897$ \\
\hline $\mathrm{TDF} / \mathrm{FTC}+\mathrm{DRV} / \mathrm{r}$ & $€ 23,069$ & $€ 19,787$ & $€ 26,352$ & $€ 22,930$ & $€ 23,209$ & $€ 24,947$ & $€ 21,574$ & $€ 22,947$ & $€ 23,|9|$ \\
\hline TDF/FTC + RAL & $€ 25,637$ & $€ 22,069$ & $€ 29,205$ & $€ 25,578$ & $€ 25,696$ & $€ 27,289$ & $€ 24,569$ & $€ 25,647$ & $€ 25,627$ \\
\hline
\end{tabular}

Abbreviations: HAART, highly active antiretroviral therapy; TDF, tenofovir; FTC, emtricitabine; RPV, rilpivirine; EFV, efavirenz; ATV, atazanavir; DRV, darunavir; RAL, raltegravir; ABC, abacavir; 3TC, lamivudine; $r$, ritonavir. 


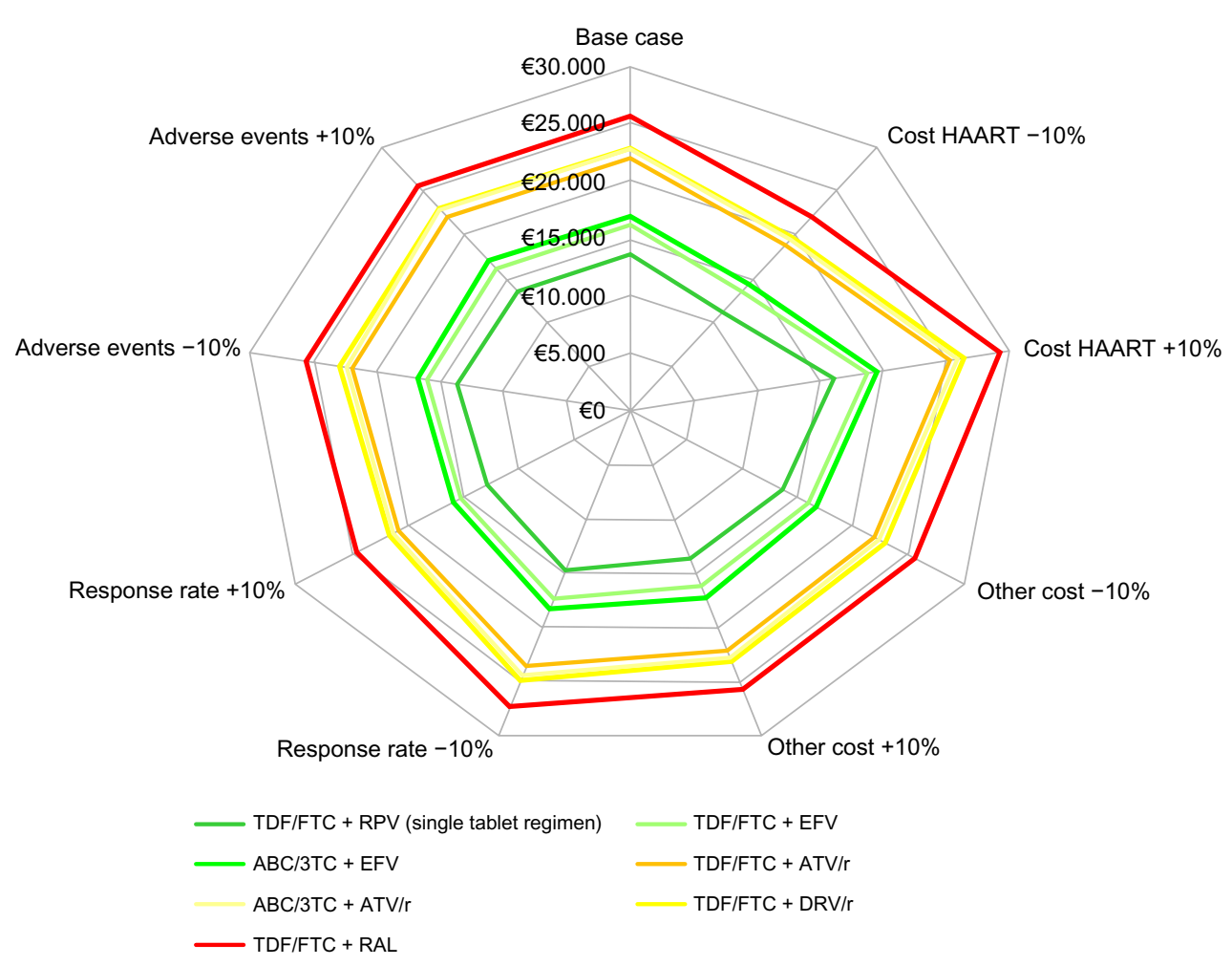

Figure 2 Results of one-way sensitivity analyses.

Abbreviations: HAART, highly active antiretroviral therapy; TDF, tenofovir; FTC, emtricitabine; RPV, rilpivirine; EFV, efavirenz; ATV, atazanavir; DRV, darunavir; RAL, raltegravir; ABC, abacavir; 3TC, lamivudine; r, ritonavir.

FTC/RPV. In the literature, however, we find a greater patient preference for STRs vs MPRs, with a better adherence of patients to treatment. ${ }^{4,37-44}$ Based on a study by Airoldi et al, ${ }^{45}$ it was therefore possible to identify the utility-score increment in patients switching from a TDF/FTC + EFV MPR to a TDF/FTC/EFV STR; in the reduction of the number of daily pills from two to one, the ADONE (Adherence to One Pill Once a Day) study measured a 3.9\% increase in QoL, from $68.8 \%$ (95\% confidence interval [CI] 67.7-70.0) to $72.7 \%$ (95\% CI 71.5-73.8) $(P=0.042)$ in health perceived by patients after 6 months, for patients who switched from an MTR to an STR. In this simplification study, patients treated with the single components of the STR switched to taking STR, thus changing only the number of pills but without modifying the pharmacological content of the therapeutic regimen. When patients took the single components, adherence (as the percentage of taken doses) was 96.1\% (95\% CI 90.4-95.4), and reached 97.1\% (95\% CI 97.0-98.4) $(P=0.014)$ after patients switched to the STR. In our analysis, we confirmed the previous study results, showing an advantage in terms of QALYs gained from STRs versus MPRs, and consequently a better ICER versus the separated components, but without any adjustment in the utility score. Adding new antiretroviral STRs to conventional therapies can help physicians in the choice of the best possible treatment to administer HIV patients. However, it is now recognized that low adherence to antiretroviral drugs is strictly linked to the failure of the therapeutic regimen, ${ }^{46}$ and consequently to HIV disease-progression indicators, such as virological failure, ${ }^{47}$ insufficient immunologic reconstitution, the clinical progression of the disease, and death. ${ }^{4,41}$ Adherence to therapy is not only necessary to obtain a therapeutic result in patients starting a treatment but also to maintain effective viral suppression over the course of time. ${ }^{48}$

This study has a few limitations, the most important of which concerns the quality of data entered into the model: parameters such as efficacy, for example, are based on studies with a limited time frame, and hence may be inadequate for modeling the treatment of a chronic disease for a longer time. ${ }^{49}$ We considered also 1-year Markov cycles, in order to include cost data that were evaluated for a 1-year time period. ${ }^{12}$ Another important limitation relates to the assumptions on which the analysis is based, which may be necessary to simplify the model or in the case of incomplete data. Specifically, this regarded transition probabilities, which were lacking in some cases and thus assumed to remain constant over time, and utilities, which were derived from different literature sources and considered to be acceptable for an Ital- 
ian population. A further limitation could be the adoption of a long-term simulation model (10 years) to compare the three alternative regimens, which was built on the basis of clinical information (now available in the literature) referring to a short-medium period. This is justified by the fact that the evaluation of the benefits and costs of a health program needs synthesis tools for representing a reality to study that are as faithful as possible, especially when the effects of the program have a time horizon with a long-term impact, or when the data sources are not homogeneous (ie, they derive from administrative records, clinical studies, and meta-analyses). ${ }^{12,49}$

Apart from the aforementioned limitations, however, the proposed results allow us to propose a pharmacoeconomic pathway to try and give a value to HIV combination therapies aimed at simplifying the daily treatment regimen in STR. The information contained in this kind of study should be supplied as a constant support to policy-makers to better allocate resources. In conclusion, it is worth observing that simulation models can assist policy-makers in comparing the relative impact and cost-effectiveness of different regimens, ${ }^{50}$ generalizing the results of randomized controlled trials to the local setting, identifying threats to program success, identifying opportunities for maximizing intervention impact/efficiency, and evaluating the extent to which observed trends in HIV prevalence are attributable to HIV/AIDS program success.

\section{Disclosure}

This research was supported by Gilead Sciences Srl, Milan, Italy. The authors are employees of independent research organizations and maintained independent scientific control over the study, including data analysis and interpretation of final results.

\section{References}

1. Porter K, Babiker A, Bhaskaran K, et al. Determinants of survival following HIV-1 seroconversion after the introduction of HAART. Lancet. 2003;362:1267-1274.

2. Bangsberg DR, Acosta EP, Gupta R, et al. Adherence-resistance relationships for protease and non-nucleoside reverse transcriptase inhibitors explained by virological fitness. AIDS. 2006;20:223-231.

3. Shuter J. Forgiveness of non-adherence to HIV-1 antiretroviral therapy. J Antimicrob Chemother. 2008;61:769-773.

4. Bangsberg DR, Perry S, Charlebois ED, et al. Non-adherence to highly active antiretroviral therapy predicts progression to AIDS. AIDS. 2001;15:1181-1183.

5. Garcia de Olalla P, Knobel H, Carmona A, Guelar A, López-Colomés JL, Caylà JA. Impact of adherence and highly active antiretroviral antiretroviral therapy on survival in HIV-infected patients. J Acquir Immune Defic Syndr. 2002;30:105-110.

6. Italian Ministry of Health - Centro Nazionale AIDS. [Italian guidelines on the use of antiretroviral drugs and the diagnostic-clinical management of HIV-infected patients]. 2012. Available from: http://www.salute.gov.it/ imgs/C_17_pubblicazioni_1793_allegato.pdf. Accessed June 28, 2013. Italian.
7. Rizzardini G, Bonfanti P, Carenzi L, et al. Cost-effectiveness analysis of HIV treatment in the clinical practice of a public hospital in northern Italy. Ther Clin Risk Manag. 2012;8:377-384.

8. Castagna A, Colombo G, Salpietro S, Galli L, Poli A, Lazzarin A. Cost-effectiveness evaluation of initial HAART regimens for managing HIV-infected patients according to real clinical practice. $J$ Int AIDS Soc. 2012;15 Suppl 4:18386.

9. Maggiolo F, Di Matteo S, Masini G, et al. Cost-effectiveness analysis of first-line HAART. J Int AIDS Soc. 2012;15 Suppl 4:18377.

10. European Medicines Agency. Eviplera - key facts. 2011. Available from: http://www.ema.europa.eu/ema/index.jsp?curl=pages/medicines/ human/medicines/002312/smops/Positive/human_smop_000277.jsp\& mid=WC0b01ac058001d127\&murl=menus/medicines/medicines.jsp. Accessed June 28, 2013.

11. Italian Medicines Agency (AIFA). - Reimbursement and price of the medicinal products Eviplera - Regime di rimborsabilità e prezzo di vendita del medicinale per uso umano Eviplera (emtricitabina/tenofovir disoproxil/rilpivirina) autorizzata con procedura centralizzata europea dalla Commissione Europea. Boll Mens Stat (Rome). 2013;35:24-25. Available from: http://www.gazzettaufficiale.it/atto/serie_generale/ caricaDettaglioAtto/originario?atto.dataPubblicazioneGazzetta=201302-11\&atto. codiceRedazionale $=13$ A00956\&elenco30giorni $=$ true. Accessed June 28,2013. Italian.

12. Colombo GL, Colangeli V, Di Biagio A, Di Matteo S, Viscoli C, Viale P. Cost-effectiveness analysis of initial HIV treatment under Italian guidelines. Clinicoecon Outcomes Res. 2011;3:197-205.

13. Italian Ministry of Health, [Italian guidelines on the use of antiretroviral drugs and the diagnostic-clinical management of HIV-infected patients]. Commissione Nazionale per la lotta contro l'AIDS. Linee Guida Italiane sull'utilizzo dei farmaci antiretrovirali e sulla gestione diagnosticoclinica delle persone con infezione da HIV-1. 2010. Available from: http://www.ristretti.it/commenti/2010/luglio/pdf4/linee_hiv_carcere. pdf. Accessed June 28, 2013. Italian.

14. Fondazione ICONA - Italian Cohort Naive Antiretrovirals.- Patients with very high pre-HAART viremia are at highest risk of experiencing virological rebound. Available from: http://www.fondazioneicona. org/_new/download/home/icar2013/Armenia.pdf. Accessed June 28, 2013.

15. Regione Emilia-Romagna. The state of HIV/AIDS infection in EmiliaRomagna. Available from: http://www.epicentro.iss.it/regioni/emilia/ pdf/ER_Hiv-Aids08.pdf. Accessed June 28, 2013. Italian.

16. Simpson KN, Luo MP, Chumney E, Sun E, Brun S, Ashraf T. Cost-effectiveness of lopinavir/ritonavir versus nelfinavir as the firstline highly active antiretroviral therapy regimen for HIV infection. HIV Clin Trials. 2004;5:294-304.

17. Pezzotti P, Angeletti C. The determinants of spending on antiretrovirals: a budget impact analysis model based on regional data. 2010. Available from: http://www.asplazio.it/asp_online/prev_for_doc/files/ formazione/aids/11/modulo_01/Pezzotti_11.pdf. Accessed June 28, 2013. Italian.

18. Italian Health Economics Association (AIES). Italian guidelines proposal on how to conduct economic evaluation studies of health programs. Pharmacoecon Ital Res Artic. 2009;11:83-93. Italian.

19. Cohen C, Wohl D, Arribas J, et al. STAR Study: single tablet regimen emtricitabine/rilpivirine/tenofovir DF is non-inferior to efavirenz/ emtricitabine/tenofovir DF in ART-naïve adults. J Int AIDS Soc. 2012;15 Suppl 4:18221.

20. Cohen CJ, Molina JM, Cahn P, et al. Efficacy and safety of rilpivirine (TMC278) versus efavirenz at 48 weeks in treatment-naive HIV-1infected patients: pooled results from the phase 3 double-blind randomized ECHO and THRIVE Trials. J Acquir Immune Defic Syndr. 2012;60:33-42.

21. Daar E, Tierney C, Fischl M, et al. ACTG 5202: Final results of $\mathrm{ABC} / 3 \mathrm{TC}$ or TDF/FTC with either EFV or ATV/r in treatment-naive HIV-infected patients. Presented at: 17th Conference on Retroviruses and Opportunistic Infections (CROI 2010); February 16-19, 2010; San Francisco, CA. 
22. Mills AM, Nelson M, Jayaweera D, et al. Once-daily darunavir/ ritonavir vs lopinavir/ritonavir in treatment-naive, HIV-1-infected patients: 96-week analysis. AIDS. 2009;23:1679-1688.

23. Orkin C, DeJeesus E, Khanlou H, et al. ARTEMIS: 192-week efficacy and safety of once-daily darunavir/ritonavir (DRV/r) versus lopinavir/r (LPV/r) in treatment-naive HIV-1-infected adults. J Int AIDS Soc. 2010;13 Suppl 4:P3.

24. Eron JJ Jr, Rockstroh JK, Reynes J, et al. Raltegravir once daily or twice daily in previously untreated patients with HIV-1: a randomised, active-controlled, phase 3 non-inferiority trial. Lancet Infect Dis. 2011;11:907-915.

25. Rockstroh JK, Lennox JL, DeJesus E, et al. Long-term treatment with raltegravir or efavirenz combined with tenofovir/emtricitabine for treatment-naive human immunodeficiency virus-1-infected patients: 156-week results from STARTMRK. Clin Infect Dis. 2011;53: 807-816.

26. Lennox JL, DeJesus E, Lazzarin A, et al. Safety and efficacy of raltegravir-based versus efavirenz-based combination therapy in treatment-naive patients with HIV-1 infection: a multicentre, double-blind randomised controlled trial. Lancet. 2009;374:796-806.

27. Rockstroh JK, DeJesus E, Lennox JL, Yazdanpanah Y, Saag MS, Wan H, Rodgers AJ, Walker ML, Miller M, DiNubile MJ, Nguyen BY, Teppler H, Leavitt R, Sklar P; STARTMRK Investigators.Durable efficacy and safety of raltegravir versus efavirenz when combined with tenofovir/emtricitabine in treatment-naive HIV-1-infected patients: final 5-year results from STARTMRK.J Acquir Immune Defic Syndr. 2013 May 1;63(1):77-85.

28. Molina JM, Cahn P, Grinsztejn B, et al. Rilpivirine versus efavirenz with tenofovir and emtricitabine in treatment-naive adults infected with HIV-1 (ECHO): a phase 3 randomised double-blind active-controlled trial. Lancet. 2011;378:238-246.

29. Cohen CJ, Andrade-Villanueva J, Clotet B, et al. Rilpivirine versus efavirenz with two background nucleoside or nucleotide reverse transcriptase inhibitors in treatment-naive adults infected with HIV-1 (THRIVE): a phase 3, randomised, non-inferiority trial. Lancet. 2011;378:229-237.

30. Fourie J, Flamm J, Rodriguez-French A, et al. Effect of baseline characteristics on the efficacy and safety of once-daily darunavir/ritonavir in HIV-1-infected, treatment-naïve ARTEMIS patients at week 96. HIV Clin Trials. 2011;12:313-322.

31. Lombardy Region, Decree-Law n. 1725, DECRETO n. 1725 del 01/03/2013 [webpage on the Internet] Therapeutic diagnostic Path of patients with HIV disease. Available from: http://www.sanita.regione. lombardia.it/cs/Satellite?c=Page\&childpagename=DG_Sanita/Page/ NormativaDetail\&pagename=DG_SANWrapper\&cid=12132759026 73\&keyid=4300. Accessed June 28,2013. Italian.

32. Rizzardini G, Restelli U, Bonfanti P, et al. Cost of human immunodeficiency virus infection in Italy, 2007-2009: effective and expensive, are the new drugs worthwhile? Clinicoecon Outcomes Res. 2012;4:245-252.

33. Jonsson B. Changing health environment: the challenge to demonstrate cost-effectiveness of new compounds. Pharmacoeconomics. 2004; 22 Suppl 4:5-10.

34. Lucioni C, Ravasio R. How to evaluate the results of a pharmacoeconomic study? Come valutare i risultati di uno studio farmacoeconomico? Pharmacoecon Ital Res Artic. 2004:121-130. Italian.

35. Messori A, Santarlasci B, Trippoli S, Vaiani M. Clinical benefit and economic value: methodology and economic application. Controvalore economico del farmaco e beneficio clinico:Stato dell'arte della metodologia e applicazione di un algoritmo farmacoeconomico. Pharmacoecon Ital Res Artic. 2003;5:53-67. Italian.

ClinicoEconomics and Outcomes Research

\section{Publish your work in this journal}

ClinicoEconomics \& Outcomes Research is an international, peerreviewed open-access journal focusing on Health Technology Assessment, Pharmacoeconomics and Outcomes Research in the areas of diagnosis, medical devices, and clinical, surgical and pharmacological intervention. The economic impact of health policy and health systems
36. Moeremans K, Annemans L, Löthgren M, et al. Cost effectiveness of darunavir/ritonavir $600 / 100 \mathrm{mg}$ bid in protease inhibitor-experienced, HIV-1-infected adults in Belgium, Italy, Sweden and the UK. Pharmacoeconomics. 2010;28 Suppl 1:107-128.

37. Maggiolo F, Ravasio L, Ripamonti D, et al. Similar adherence rates favour different virologic outcomes for patients treated with nonnucleoside analogues or protease inhibitors. Clin Infect Dis. 2005;40: $158-163$.

38. Deschamps AE, De Graeve V, Van Wijngaerden E, et al. Prevalence and correlates of nonadherence to antiretroviral therapy in a population of HIV patients using Medication Event Monitoring System. AIDS Patient Care STDS. 2004;18:644-657.

39. Diabate S, Alary M, Koffi CK. Determinants of adherence to highly active antiretroviral therapy among HIV-1-infected patients in Cote d'Ivoire. AIDS. 2007;21:1799-1803.

40. Stone VE, Jordan J, Tolson J, Miller R, Pilon T. Perspectives on adherence and simplicity of HIV-infected patients on antiretroviral therapy. Self-report of the relative importance of multiple attributes of highly active antiretroviral therapy (HAART) regimens in predicting adherence. J Acquir Immune Defic Syndr. 2004;36:808-816.

41. Lima VD, Harrigan R, Bangsberg DR, et al. The combined effect of modern highly active antiretroviral therapy regimens and adherence on mortality over time. J Acquir Immune Defic Syndr. 2009;50:529-536.

42. Sax PE, Meyers JL, Mugavero M, Davis KL. Adherence to antiretroviral treatment and correlation with risk of hospitalization among commercially insured HIV patients in the United States. PLoS One. 2012;7:e31591.

43. Sterrantino G, Santoro L, Bartolozzi D, Trotta M, Zaccarelli M. Self-reported adherence supports patient preference for the single tablet regimen (STR) in the current cART era. Patient Prefer Adherence. 2012;6:427-433.

44. Antinori A, Marcotullio S, Ammassari A, et al. Italian guidelines for the use of antiretroviral agents and the diagnostic-clinical management of HIV-1 infected persons. Update 2011. New Microbiol. 2012;35:113-159.

45. Airoldi M, Zaccarelli M, Bisi L, et al. One-pill once-a-day HAART: a simplification strategy that improves adherence and quality of life of HIV-infected subjects. Patient Prefer Adherence. 2010;4:115-125.

46. D’Arminio Monforte A, Lepri AC, Rezza G, et al. Insights into the reasons for discontinuation of the first highly active antiretroviral therapy (HAART) regimen in a cohort of antiretroviral naïve patients. I.CO.N.A. Study Group. Italian Cohort of Antiretroviral-Naïve Patients. AIDS. 2000;14:499-507.

47. Paterson DL, Swindells S, Mohr J, et al. Adherence to protease inhibitor therapy and outcomes in patients with HIV infection. Ann Intern Med. 2000;133:21-30.

48. Antinori A, Cozzi-Lepri A, Ammassari A, et al. Relative prognostic value of self-reported adherence and plasma NNRTI/PI concentrations to predict virological rebound in patients initially responding to HAART. Antivir Ther. 2004;9:291-296.

49. Colombo GL, Gaeta GB, Viganò M, Di Matteo S. A cost-effectiveness analysis of different therapies in patients with chronic hepatitis B in Italy. Clinicoecon Outcomes Res. 2011;3:37-46.

50. Johnson LF, White PJ. A review of mathematical models of HIV/AIDS interventions and their implications for policy. Sex Transm Infect. 2011;87:629-634

organization also constitute important areas of coverage. The manuscript management system is completely online and includes a very quick and fair peer-review system, which is all easy to use. Visit http://www.dovepress.com/testimonials.php to read real quotes from published authors. 